\title{
ANALISIS EKSPOR KOPI INDONESIA KE NEGARA-NEGARA ASEAN
}

\author{
Christian Putra Ginting ${ }^{1}$, Fitri Kartiasih ${ }^{2}$ \\ ${ }^{1}$ BPS Kabupaten Lembata; ${ }^{2}$ Politeknik Statistika STIS \\ Jl. Trans Lembata - Lewoleba; Jl. Otista No. 64 C Jakarta \\ e-mail: ${ }^{1}$ christian.ginting @gmail.com, ${ }^{2}$ fkartiasih@ stis.ac.id
}

diterima: 5/7/2019; direvisi: 17/9/2019; diterbitkan: 24/9/2019

\begin{abstract}
Responding to the era of the ASEAN Economic Community (MEA), Indonesian agricultural products, especially coffee, have economic value that can be developed and traded in the ASEAN market in order to increase market share and diversify the destination countries for Indonesian product exports. The purpose of this study is to provide an overview of coffee production and exports in ASEAN countries, analyze the performance of Indonesian coffee exports to ASEAN countries and analyze the factors that influence Indonesian coffee exports in the period 1997-2014. Indonesian coffee production over the past 12 years has shown stagnation in the range of 640 - 700 thousand tons. However, coffee exports show increasing developments in Malaysia, Thailand and Vietnam as well as stagnant exports and tend to decline in the Philippines and Singapore. Based on the RCA and EPD indices, the performance of Indonesia's coffee exports has the highest comparative advantage in the country of Malaysia which is also evidenced by the position of the country along with Vietnam in the rising star quadrant. From the results of panel data regression analysis at a significance level of 5 percent, Indonesian coffee exports in ASEAN countries are influenced by real export price variables, tea prices, destination country GDP, destination country real exchange rates, and RCA competitiveness index. Meanwhile, the variable domestic coffee production has no significant effect on Indonesian coffee exports.
\end{abstract}

Keywords: ASEAN, coffee, competitiveness, exports, panel data regression

\section{PENDAHULUAN}

Era Masyarakat Ekonomi ASEAN (MEA) merupakan integrasi pasar internasional yang memungkinkan negara-negara anggotanya untuk memasuki pasar domestik dengan bebas dengan pengurangan tarif perbatasan hingga ke nol persen (Tambunan, 2011). Integrasi ekonomi ini menyebabkan adanya dampak aliran bebas barang, jasa, investasi, tenaga kerja terampil, dan modal bagi negara-negara ASEAN. Kawasan ASEAN merupakan tujuan dagang Indonesia yang potensial dalam rangka meningkatkan pangsa pasar dan diversifikasi negara tujuan ekspor. Indonesia memiliki potensi untuk menjadi pelaku maupun tujuan perdagangan di ASEAN melihat jumlah populasi, luas geografi, dan nilai PDB yang merupakan terbesar di kawasan tersebut (Winantyo et. al, 2008).
Walaupun pertumbuhan PDB rentang tahun 2000-2014 memiliki rata-rata 5,05 persen (BPS, 2014) namun Indonesia menunjukkan ketergantungan dengan pasar luar negeri dimana pertumbuhan ekspor Indonesia pada tahun 2007-2013 mencapai 8,85 persen sedangkan pertumbuhan impornya mencapai 16 persen (ASEAN, 2014).

Menanggapi hal itu, pengembangan dan pemanfaatan sumber daya yang berlimpah terutama pertanian perlu ditingkatkan untuk meningkatkan kinerja ekspor Indonesia. Ekspor pertanian terutama kopi menunjukkan share tertinggi dibandingkan komoditikomoditi ekspor pertanian lainnya yakni menyumbang 382.750 ton atau sekitar 12,1 persen dari total ekspor pertanian (BPS, 2014).

Tanaman kopi merupakan komoditas ekspor yang mempunyai nilai 


\section{Jurnal Ilmiah Ekonomi dan Bisnis}

Vol. 16. No.2, September 2019: 143-157

EISSN : $2442-9813$

ISSN : $1829-9822$

ekonomis yang relatif tinggi di pasaran dunia. Di dalam perdagangan internasional, Indonesia menjadi salah satu negara pengekspor utama komoditi kopi dunia. Tahun 2014, Indonesia menjadi negara pengekspor kopi urutan keempat setelah Brazil, Vietnam dan Colombia. Berdasarkan United Nation Commodity Trade (2016), pada tahun 2014 Brazil mempunyai andil hingga 14,7 persen ekspor kopi dunia serta diikuti dengan Indonesia pada urutan keempat yang menyumbang hanya 2,8 persen dari total ekspor dunia. Pada tahun yang sama, Vietnam sebagai negara eksportir kopi utama menyumbang 12,1 persen ekspor kopi dunia. Hal tersebut berbeda jauh dengan proporsi kopi yang diekspor dari Indonesia. Dengan kata lain, terciptanya pasar bebas ASEAN ini akan membuat pasar internasional regional ASEAN tersebut dibanjiri oleh ekspor kopi dari Vietnam.

Tabel 1.Ekpor komoditi kopi negaranegara pengekspor utama (ton)

\begin{tabular}{|l|l|l|l|}
\hline \multirow{2}{*}{ Negara } & \multicolumn{3}{|l|}{ Tahun } \\
\cline { 2 - 4 } & 2012 & 2013 & 2014 \\
\hline Brazil & 1.503 .707 & 1.699 .145 & 1.986 .500 \\
\hline Vietnam & 1.697 .352 & 1.253 .982 & 1.631 .756 \\
\hline Colombia & 395.517 & 542.820 & 617.959 \\
\hline Indonesia & 447.011 & 532.140 & 382.750 \\
\hline $\begin{array}{l}\text { Total 4 } \\
\text { negara }\end{array}$ & 4.043 .587 & 4.028 .087 & 4.618 .964 \\
\hline $\begin{array}{l}\text { Total } \\
\text { dunia }\end{array}$ & 12.099 .614 & 11.828 .789 & 13.537 .617 \\
\hline
\end{tabular}

Sumber : UNCOMTRADE

Keterangan: HS 090111

Meskipun Indonesia tergolong sebagai salah satu negara pengekspor utama komoditi kopi, namun Indonesia masih gagal memanfaatkan area lahan yang potensial untuk dapat memproduksi kopi. Hal ini terlihat dari rendahnya produktivitas produksi kopi di dalam negeri. Berdasarkan data FAO, produksi kopi Indonesia tahun 2010 dan 2013 menduduki peringkat ketiga setelah Brazil dan Vietnam. Indonesia menyumbang produksi sekitar 11,0 persen dari total produksi kopi dunia pada tahun 2013. Di sisi lain, Brazil mampu memproduksi 46,8 persen kopi dan diikuti Vietnam 23,1 persen dari total produksi dunia pada tahun 2013.

Produktivitas kopi Indonesia masih jauh dari produktivitas kopi negara pesaingnya di regional ASEAN. Meskipun Indonesia memiliki lahan panen kopi mencapai 1,2 juta hektar, namun produksi kopi hanya mencapai $563 \mathrm{~kg}$ per hektar pada tahun 2013. Berbeda halnya dengan Vietnam yang memiliki luas lahan panen hanya mencapai 584 ribu hektar, negara ini mampu memproduksi kopi hingga mencapai $2.499 \mathrm{~kg}$ per hektar pada tahun yang sama. Dengan kata lain, dengan luas lahan setengah kali luas lahan panen kopi Indonesia, Vietnam mampu memproduksi hingga dua kali jumlah produksi kopi Indonesia.

Tabel 2. Produksi, luas panen dan produktivitas kopi negara pengekspor utama tahun 2013

\begin{tabular}{|l|l|l|c|}
\hline Negara & $\begin{array}{l}\text { Produksi } \\
\text { (Ton) }\end{array}$ & $\begin{array}{l}\text { Luas } \\
\text { Panen } \\
(\mathrm{Ha})\end{array}$ & $\begin{array}{l}\text { Produktivitas } \\
(\mathrm{Kg} / \mathrm{Ha})\end{array}$ \\
\hline Brazil & 2.964 .538 & 2.085 .522 & 1.421 \\
\hline Vietnam & 1.461 .000 & 584.600 & 2.499 \\
\hline Colombia & 653.160 & 771.728 & 846 \\
\hline Indonesia & 698.900 & 1.240 .900 & 563 \\
\hline $\begin{array}{l}\text { Total } \\
\text { negara }\end{array}$ & 5.777 .598 & 4.682 .750 & \\
\hline $\begin{array}{l}\text { Total } \\
\text { dunia }\end{array}$ & 6.337 .338 & 7.126 .726 & \\
\hline Sumber & FAO & \\
\hline
\end{tabular}

Sumber : FAO, HS 090111

Produktivitas kopi Indonesia yang kurang optimal dapat menyebabkan kurangnya stok komoditi kopi yang dapat ditawarkan kepada negara-negara pengimpor kopi. Tingginya produktivitas kopi Vietnam memungkinkan produk negara tersebut dapat membanjiri pasar kopi ASEAN sehingga berdampak terhadap ekspor kopi Indonesia seperti di Singapura dan Filipina. Di samping itu, kopi Indonesia juga memiliki potensi dengan varietas yang hanya terdapat di 
Indonesia seperti Kopi Sidikalang, Kopi Lintong dan Kopi Mandheling dari Sumatera, Kopi Toraja dari Sulawesi, Kopi Gayo dari Aceh, Kopi Bali Kintamani dari Bali, Kopi Papua Wamena, Kopi Flores Bajawa dari Kabupaten Ngada dan Kopi Luwak yang merupakan jenis kopi dengan harga paling mahal (Nurjanah, 2015). Banyaknya jenis kopi Indonesia menyebabkan negara-negara produsen kopi seperti Vietnam masih tetap mengimpor kopi dari Indonesia sehingga masih memungkinkan untuk bersaing di pasar ASEAN.

Selain itu kualitas kopi Indonesia yang terdapat di pasar Internasional yang lebih rendah dari kopi negaranegara eksportir kopi lainnya menjadi faktor penghambat bagi nilai ekspor kopi Indonesia. International Coffee Organization (ICO) mencatat Indonesia adalah salah satu negara yang mengekspor kopi terutama jenis robusta yang mencapai 150 kecacatan dalam 300 gram biji kopinya. Dilihat dari sisi harga, pada tahun 2013 harga jual kopi Indonesia jenis robusta pada bulan Juni hanya 79,7 cent dolar AS dimana harga pasar internasional untuk jenis ini 90,79 cent dolar AS. Hal itu juga tidak jauh berbeda pada bulan Juli dan Agustus dimana harga jual kopi Indonesia jenis robusta berturut-turut 84,06 dan 83,03 cent dolar AS dimana harganya di pasar internasional berturut-turut 95,21 dan 94,01 cent dolar AS.

Di samping itu, kurangnya pengolahan terhadap produksi kopi Indonesia membuat nilai ekspornya lebih rendah dan tidak kompetitif dengan ekspor kopi dari negara lainnya. Berdasarkan BPS (2013), ekspor kopi Indonesia terdiri dari $86,5 \%$ biji kopi mentah, $11,4 \%$ kopi instan, $1,7 \%$ kopi ekstrak, dan 0,2\% roasted coffee. Ekspor kopi Indonesia ini didominasi oleh kopi biji yang merupakan bahan baku sehingga kurang memiliki nilai ekonomi dibanding dengan produk olahan kopi. Hal ini menyebabkan harga jual kopi di pasar internasional tidak maksimal.

Negara-negara ASEAN bukanlah negara tujuan utama ekspor komoditi kopi Indonesia, namun nilai ekspor kopi yang fluktuatif dan adanya integrasi ekonomi regional tersebut menunjukkan bahwa ASEAN berpotensi menjadi target pasar ekspor kopi Indonesia ke depan. Dengan adanya perjanjian perdagangan bebas ke depan, komoditi kopi akan semakin mudah untuk dipasarkan di negara-negara ASEAN lainnya. Bukan hanya bagi Indonesia, dalam perjanjian dagang regional ini, negara mitra dagang juga memiliki kesempatan yang sama untuk dapat memasarkan barang negaranya di dalam pasar Indonesia. Hal ini akan menimbulkan persaingan yang kompetitif bagi setiap negara anggota ASEAN. Indonesia yang dituntut untuk dapat menjadi pemain dalam perdagangan bebas ASEAN perlu mengkaji bagaimana dan apa yang memengaruhi ekspor komoditi kopi Indonesia guna meningkatkan ekspornya.

Tabel 3. Ekspor komoditi kopi Indonesia ke negara-negara ASEAN (ton)

\begin{tabular}{|l|r|r|r|}
\hline \multirow{2}{*}{ Negara } & & Tahun & \\
\cline { 2 - 4 } & 2012 & 2013 & 2014 \\
\hline Malaysia & 34.291 & 42.098 & 30.787 \\
\hline Filippina & 11.727 & 10.375 & 2.731 \\
\hline $\begin{array}{l}\text { Singapur } \\
\text { a }\end{array}$ & 9.157 & 8.679 & 7.727 \\
\hline Thailand & 735 & 24.289 & 8.918 \\
\hline Vietnam & 3.646 & 5.852 & 5.813 \\
\hline
\end{tabular}

Sumber : UNCOMTRADE

\section{TINJAUAN PUSTAKA}

Penelitian sebelumnya mengenai daya saing ekspor kopi menggunakan metode dan mendapatkan hasil yang berbeda-beda. Waheed dan Abbas (2015) menyelidiki faktor makroekonomi yang memengaruhi aliran bilateral ekspor dan memperkirakan potensi ekspor Bahrain 
Jurnal Ilmiah Ekonomi dan Bisnis

Vol. 16. No.2, September 2019: 143-157

EISSN : $2442-9813$

ISSN : $1829-9822$

dengan negara mitra dagang utama menggunakan Augmented version of Gravity Model pada data dari 31 negara untuk periode tahun 1994-2013. Hasil penelitiannya menunjukkan bahwa tingkat penyusutan nilai tukar riil dan cadangan mata uang asing negara-mitra dagang signifikan berpengaruh secara positif terhadap aliran ekspor Bahrain. Selain itu, dummy Free Trade Agreement (FTA) dan keanggotaan Gulf Cooperation Council (GCC) juga signifikan berpengaruh secara positif terhadap aliran ekspor yang menunjukkan pentingnya kesepakatan perdagangan bebas dan integrasi ekonomi Gulf bagi ekspor Bahrain.

Hussien (2015) melakukan estimasi faktor penentu dari pasokan ekspor kopi Ethiopia menggunakan Error Correction Model untuk data tahun 1965-2005. Variabel yang digunakan antara lain curah hujan, harga domestik, tenaga kerja pertanian, nilai tukar mata uang riil, tingkat suku bunga domestik, tingkat arus modal asing, tingkat kapasitas penggunaan, pendapatan riil, dan term of trade. Hasil penelitiannya menyatakan bahwa ekspor kopi Ethiopia dalam jangka pendek ditentukan oleh nilai tukar riil, aliran masuk modal asing, pendapatan riil, dan term of trade. Sedangkan dalam jangka panjang ekspor kopi Ethiopia ditentukan oleh harga domestik, nilai tukar riil, pendapatan riil, dan term of trade. Dalam jangka panjang, elastisitas harga sangat tinggi namun berbeda pada jangka pendek, elastisitas harga justru rendah.

Ademe dan Yismaw (2013) melakukan studi yang bertujuan untuk menganalisis pola perdagangan kopi Ethiopia selama 16 tahun dari tahun 1997-2011 ke 36 negara pengimpor. Penelitiannya menggunakan metode Gravity Data Panel untuk mengidentifikasi bagaimana pengaruh negara-negara importir dan eksportir terhadap perdagangan kopi Ethiopia. Adapun variabel yang digunakan yaitu nilai PDB Ethiopia, nilai PDB negara mitra dagang, jumlah penduduk Ethiopia, jumlah penduduk negara mitra dagang, nilai tukar mata uang dan penanaman modal asing. Hasil penelitian menyimpulkan bahwa variabel dari negara mitra dagang signifikan berpengaruh terhadap nilai ekspor kopi Ethiopia yaitu PDB negara mitra dagang. Sedangkan variabel domestik tidak signifikan berpengaruh terhadap nilai ekspor kopi Ethiopia.

Penelitian mengenai integrasi pasar dan dampak kebijakan non tarif terhadap permintaan ekspor dan daya saing kopi Indonesia di pasar internasional juga dilakukan oleh Muzendi (2014). Data yang digunakan adalah data time series dari tahun 1970 sampai 2012. Metode penelitian yang digunakan adalah uji kointegrasi pendekatan Error Correction Model (ECM) untuk menganalisis integrasi pasar sedangkan Revealed Comparative Advantage (RCA) dan Revealed Symetric Comparative Advantage (RSCA) digunakan untuk menganalisis integrasi pasar dan dampak kebijakan non tarif terhadap permintaan ekspor dan daya saing kopi. Analisis ECM menunjukkan adanya integrasi jangka pendek dengan pasar importir maupun pasar eksportir utama, dimana kecepatan penyesuaian ke keseimbangan $87,33 \%$ pada pasar importir dan $65,33 \%$ pada pasar eksportir. Variabel yang signifikan memengaruhi harga ekspor kopi Indonesia pada jangka pendek adalah harga impor kopi Amerika Serikat, Malaysia dan Singapura serta harga ekspor kopi Brazil dan Vietnam. Kopi Indonesia memiliki keunggulan komparatif dilihat berdasarkan nilai RCA dan RSCA, namun masih lebih rendah dibandingkan Brazil, Kolombia, dan Vietnam.

Izzany (2015) menganalisis kinerja ekspor kopi Indonesia di pasar ASEAN 
dalam skema kebijakan Common Effective Preferential Tariff - ASEAN Free Trade Area (CEPT-AFTA). Penelitiannya bertujuan untuk menganalisis faktor-faktor yang memengaruhi ekspor kopi Indonesia dan dampak penerapan skema CEPT-AFTA terhadap ekspor kopi Indonesia ke pasar ASEAN menggunakan model analisis linier berganda diestimasi dengan metode Ordinary Least Square (OLS). Hasil estimasi analisis regresi linier berganda pada empat negara (Malaysia, Singapura, Filipina, dan Thailand) menunjukkan bahwa faktor-faktor yang memengaruhi ekspor kopi Indonesia ke pasar ASEAN adalah pendapatan per kapita negara tujuan ekspor, nilai tukar riil Indonesia, konsumsi domestik kopi Indonesia, harga riil ekspor, produksi kopi Indonesia, dan ekspor kopi Indoensia tahun sebelumnya. Sedangkan kebijakan CEPT-AFTA tidak berpengaruh nyata terhadap ekspor kopi Indonesia ke pasar ASEAN.

Berdasarkan latar belakang permasalahan di atas, penelitian ini bertujuan untuk memberikan gambaran produksi dan ekspor kopi di negaranegara ASEAN, menganalisis kinerja ekspor kopi Indonesia ke negara-negara ASEAN serta menganalisis faktor-faktor yang berpengaruh terhadap ekspor kopi Indonesia tersebut periode tahun 19972014.

Analisis ekspor kopi Indonesia ke negara-negara ASEAN dalam penelitian ini menggunakan variabel harga kopi ekspor Indonesia, harga teh sebagai barang substitusi, PDB mitra dagang, produksi kopi domestik, nilai tukar (kurs) riil negara-negara mitra dagang terhadap US \$, dan indeks Revealed Comparative Advantage (RCA). Penelitian ini menggunakan data berkala mulai dari tahun 1997 hingga tahun 2014 pada wilayah perdagangan bilateral ASEAN 5 yaitu Malaysia, Filipina, Singapura, Thailand, dan Vietnam.
Pemilihan ini dikarenakan keterbatasan ketersediaan data untuk semua variabel di semua negara ASEAN sebagai obyek penelitian.

\section{METODE PENELITIAN}

Data yang digunakan dalam penelitian ini adalah data tahunan dan data sekunder yang diperoleh dari instansi terkait dengan rincian data volume ekspor kopi Indonesia dan harga riil ekspor kopi diperoleh dari Badan Pusat Statistik (BPS), harga komoditi teh diperoleh dari UNCOMTRADE, PDB riil diperoleh dari World Bank, dan jumlah produksi kopi domestik diperoleh dari Kementerian Pertanian, nilai tukar (kurs) riil diperoleh dari International Financial Statistics yang diterbitkan oleh International Monetary Fund (IMF). Periode penelitian yaitu tahun 1997-2014.

Metode analisis yang digunakan dalam penelitian ini yaitu penelitian deskriptif dengan menggunakan tabel dan grafik serta menggunakan perhitungan indeks RCA dan EPD untuk menganalis kinerja ekspor kopi Indonesia. Adapun rumusan indeks RCA sebagai berikut (Tambunan, 2000).

$$
\text { Indeks RCA }=\frac{\mathrm{X}_{\mathrm{ij}} / \mathrm{X}_{\mathrm{it}}}{\mathrm{W}_{\mathrm{j}} / \mathrm{w}_{\mathrm{t}}}
$$

Export Product Dynamic (EPD) dapat diformulasikan sebagai berikut (Kemendag, 2011).

Sumbu x: Rata-rata pertumbuhan pangsa pasar ekspor negara $i=$

$$
\frac{\sum_{\mathrm{t}=1}^{\mathrm{t}}\left(\frac{\mathrm{X}_{\text {in }}}{\mathrm{W}_{\text {in }}}\right)_{\mathrm{t}} \times 100 \%-\sum_{\mathrm{t}=1}^{\mathrm{t}}\left(\frac{\mathrm{X}_{\text {in }}}{\mathrm{W}_{\text {in }}}\right)_{\mathrm{t}-1} \times 100 \%}{\mathrm{~T}}
$$

Sumbu y: Rata-rata pertumbuhan pangsa pasar produk $n=$

$$
\frac{\sum_{\mathrm{t}=1}^{\mathrm{t}}\left(\frac{\mathrm{W}_{\text {in }}}{\mathrm{W}_{\mathrm{i}}}\right)_{\mathrm{t}} \times 100 \%-\sum_{\mathrm{t}=1}^{\mathrm{t}}\left(\frac{\mathrm{W}_{\text {in }}}{\mathrm{W}_{\mathrm{i}}}\right)_{\mathrm{t}-1} \times 100 \%}{\text { Analisis }}
$$
memengaruhi permintaan ekspor kopi Indonesia di ASEAN dilakukan 


\section{Jurnal Ilmiah Ekonomi dan Bisnis}

Vol. 16. No.2, September 2019: 143-157

EISSN : $2442-9813$

ISSN : $1829-9822$

menggunakan analisis regresi data panel dengan model sebagai berikut.

LNVOLXKOPI $_{i t}=\alpha+\beta_{1}$ HXKOPI $_{\text {it }}+\beta$

$\beta_{4}$ PRODKOPI $_{\text {it }}+\beta_{5}$ KURSR $_{\text {it }}+\beta_{6}$ LNRCA $_{\text {it }}+\varepsilon_{\text {it }}^{400000}$

(4)

Hipotesis penelitian ini antara lain harga ekspor riil kopi (HXKOPI) dan nilai tukar mata uang riil negara mitra dagang (KURSR) berpengaruh negatif terhadap ekspor komoditi kopi (LNVOLXKOPI). Harga barang substitusi (HMTEH), PDB riil negara mitra dagang (PDBHK), jumlah produksi kopi domestik (PRODKOPI) dan indeks daya saing (LNRCA) berpengaruh positif terhadap ekspor komoditi kopi Indonesia.

\section{HASIL DAN PEMBAHASAN}

Produksi kopi berkaitan dengan jumlah komoditi kopi yang akan ditawarkan terhadap pasar domestik maupun pasar luar negeri. Berdasarkan Gambar 1, terlihat bahwa perkembangan produksi kopi Indonesia selama kurang dari 12 tahun terakhir mengalami stagnansi yakni berada pada kisaran 640 ribu hingga 700 ribu ton. Hal ini disebabkan karena masih rendahnya produktivitas kopi Indonesia. Produksi kopi Indonesia sekitar 91 - 96 persen selama periode penelitian berasal dari perkebunan yang dikelola oleh rakyat sehingga terdapat keterbatasan modal dan sumber daya serta sisanya dikelola oleh negara dan swasta. Hal ini menyebabkan pengelolaan kopi masih buruk mulai dari bibit kopi yang digunakan, pemeliharaan tanaman, hingga penggunaan teknologi yang masih tradisional sehingga produktivitasnya masih jauh di bawah negara penghasil kopi lainnya seperti Brazil dan Vietnam (Izzany, 2015).
200000

0

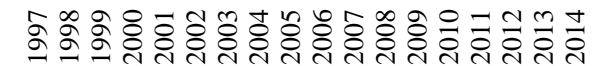

- Perkebunan Rakyat $\square$ Perkebunan Negara

- Perkebunan Swasta

Sumber : Kementerian Pertanian (diolah) Gambar 1.

Produksi kopi Indonesia tahun 1997-2014 (ton)

Selain itu, berdasarkan data Kementan tahun 2010-2014, produksi kopi Indonesia 73-79 persen didominasi oleh kopi jenis robusta dan sisanya merupakan kopi jenis arabika. Kopi robusta memiliki kelebihan tahan terhadap penyakit daun dan memerlukan perawatan yang cenderung mudah. Namun kualitas cita rasa kopi robusta tidak lebih baik dari kopi arabika sehingga kurang memiliki daya jual. Kopi arabika memiliki nilai jual yang lebih mahal karena memiliki cita rasa yang baik.

Kinerja ekspor kopi Indonesia tidak hanya diukur dari laju pertumbuhan (nilai atau volume), tetapi juga terlihat dari tingkat diversifikasinya, baik dalam arti variasi produk (pendalaman struktur) maupun diversifikasi pasar (negara tujuan). Meskipun pasar ASEAN bukan merupakan pasar utama ekspor komoditi ekspor Indonesia, namun pasar ASEAN merupakan pasar yang potensial dalam rangka memperluas tujuan ekspor komoditi Indonesia. Komoditi kopi Indonesia mulai banyak diperdagangkan mengingat mulai banyaknya variasi pengolahan kopi yang dikembangkan seiring dengan semakin majunya teknologi dan pengetahuan. Selain itu, pemasaran komoditi kopi di Indonesia pun terus semakin gencar dengan adanya 
peran serta pemerintah melalui kegiatan pemberdayaan dan edukasi mengenai teknik budi daya, pengolahan pasca panen dan pemasaran (Ariyanti, 2016).

Indonesia merupakan salah satu produsen sekaligus pengekspor utama keempat komoditi kopi dunia setelah negara Brazil, Vietnam, dan Colombia. Komoditi kopi Indonesia tersebar di seluruh pangsa pasar negara-negara dunia termasuk di kawasan ASEAN (Gambar 2). Indonesia telah lama melakukan ekspor komoditi kopi ke pasar ASEAN, namun volume ekspor komoditi kopi Indonesia sendiri cederung fluktuatif dan masih cenderung lebih rendah dibanding negara-negara pengimpor utama komoditi kopi Indonesia lainnya. Meskipun permintaan komoditi kopi Indonesia di pasar ASEAN memiliki kecenderungan fluktuatif, ekspor komoditi kopi Indonesia dalam jangka panjang menunjukkan tren yang positif secara umum. Ekspor komoditi kopi Indonesia ke lima negara ASEAN mencapai 5-17 persen dari total ekspor kopi Indonesia ke seluruh negara pada periode 19972014. Rata-rata ekspor kopi Indonesia ke lima negara ASEAN mencapai 35.977 ton $(5 \%)$ dengan ekspor kopi terendah pada tahun 1997 yakni sebesar 16.151 ton dan tertinggi 91.295 ton $(17,1 \%)$.

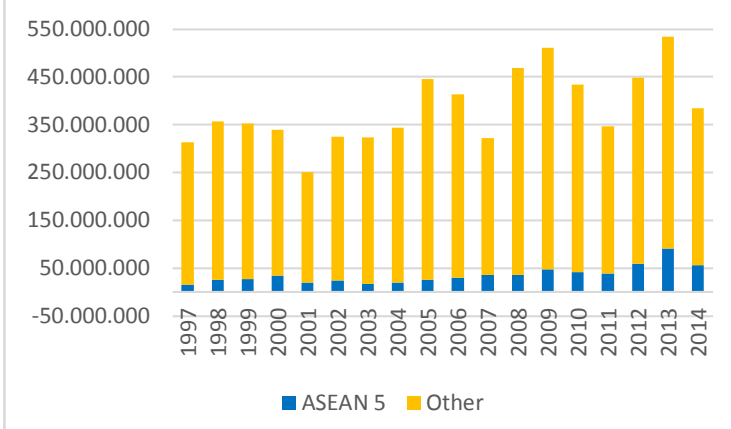

Sumber : UN Comtrade (diolah)

Gambar 2.

Perkembangan volume ekspor kopi Indonesia ke seluruh negara di dunia $(\mathrm{kg})$
Gambar 2 menunjukkan volume ekspor komoditi kopi Indonesia ke 5 negara ASEAN tahun 1997-2014. Rata-rata permintaan ekspor komoditi kopi Indonesia di negara Malaysia pada periode waktu tersebut mencapai 16.045 ton. Permintaan ekspor kopi Indonesia di negara Malaysia cenderung meningkat dari tahun ke tahun. Peningkatan permintaan ekspor tersebut menunjukkan peningkatan yang mencapai di atas ratarata terjadi sejak tahun 2008. Permintaan ekspor tertinggi terjadi pada tahun 2013 mencapai 42.098 ton atau menyumbang devisa negara sebesar 79,7 juta dolar AS. Peningkatan tertinggi terjadi pada tahun 2010 dimana volume ekspor kopi Indonesia mencapai $48 \%$ dibanding tahun 2009. Berbeda dengan negara Filipina, ekspor kopi Indonesia ke negara Filipina terlihat cenderung sangat fluktuatif. Ratarata ekspor komoditi kopi Indonesia ke negara Filipina mencapai 6.208 ton.

Ekspor komoditi kopi Indonesia cenderung tinggi yakni di atas rata-rata pada tahun 2007-2009 dan mengalami penurunan tajam pada tahun 2011 dan 2014.

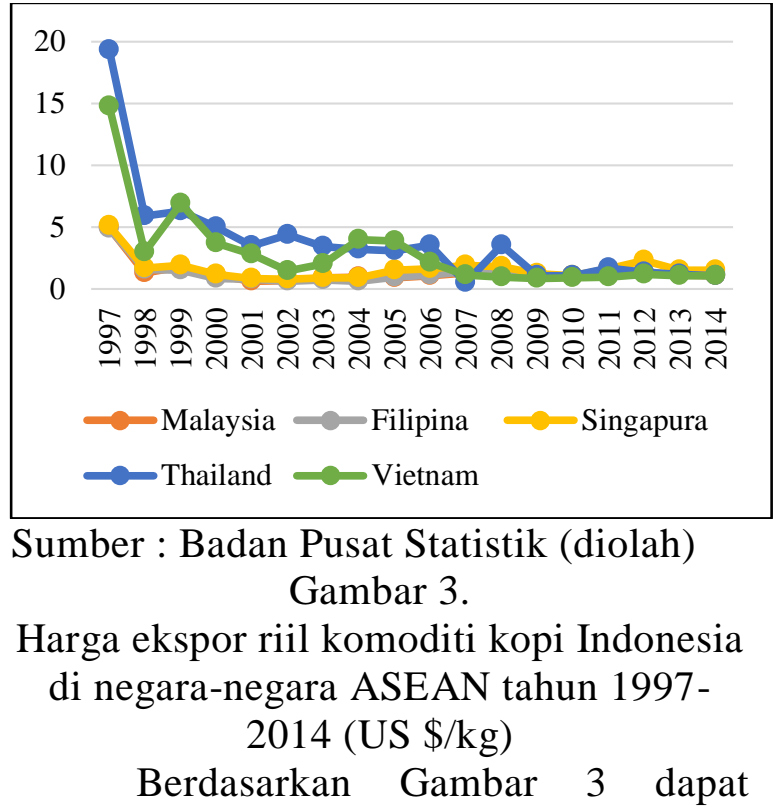
dilihat bahwa harga riil ekspor komoditi kopi Indonesia ke negara Thailand dan Vietnam dari tahun ke tahun terlihat 
Jurnal Ilmiah Ekonomi dan Bísnis

Vol. 16. No.2, September 2019: 143-157

EISSN : 2442 - 9813

ISSN : $1829-9822$

fluktuatif dan mengalami penurunan.

Rata-rata harga riil komoditi kopi Indonesia di Thailand dan Vietnam mencapai masing-masing 2,94 dan 2,25 US \$ per kg selama periode penelitian. Harga riil komoditi kopi tertinggi terdapat pada tahun 1997 mencapai 19,32 US \$ untuk Thailand dan 14,74 US \$ untuk Vietnam. Tingginya harga ekspor komoditi kopi di tahun tersebut dikarenakan adanya kondisi krisis ekonomi yang terjadi dikawasan Asia Timur. Walaupun cenderung mengalami penurunan, sebelum tahun 2007, harga riil komoditi kopi Indonesia di kedua negara tersebut masih lebih mahal dibandingkan ketiga negara lainnya yakni Malaysia, Filipina, dan Singapura. Harga riil komoditi kopi terendah terdapat pada tahun 2007 sebesar 0,52 US \$ untuk Thailand dan tahun 2009 sebesar 0,88 US \$ untuk Vietnam. Pada tahun 2007-2009, harga komoditi kopi di Thailand mengalami fluktuatif yang cukup tajam. Hal ini berkaitan dengan terjadinya krisis ekonomi di Amerika yang berdampak ke negara-negara Asia. Namun demikian, harga riil komoditi kopi di Thailand cenderung stabil sejak tahun 2009 pada kisaran 1,07 hingga 1,69 US \$ per kg.

Berbeda dengan harga riil komoditi kopi di Vietnam, harga riil komoditi tersebut cenderung menurun dengan drastis mulai tahun 2005 hingga mulai stabil pada tahun 2007 pada kisaran 0,88 hingga 1,20 US \$ per kg.

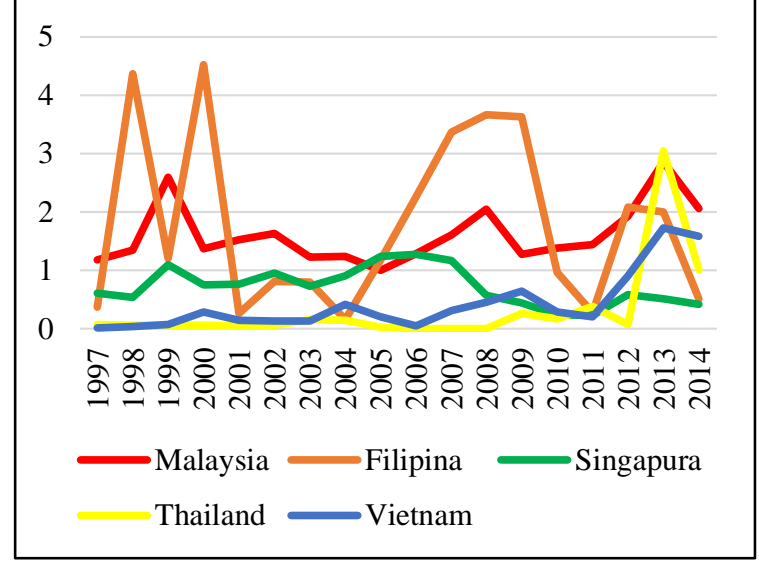

Sumber : UN Comtrade (diolah)

Gambar 4.

Perkembangan indeks RCA ekspor komoditi kopi Indonesia di negara negara ASEAN tujuan ekspor tahun 1997-2014

Gambar 4 menunjukkan bahwa indeks Revelead Comparative Advantage (RCA) ekspor komoditi kopi Indonesia ke lima negara tujuan ekspor di ASEAN menunjukkan perkembangan yang fluktuatif. Pada pasar Malaysia, dapat dikatakan bahwa komoditi kopi sangat diminati di negara tersebut. Hal itu terlihat dari nilai RCA yang salalu di atas angka satu yang mengindikasikan bahwa ekspor kopi Indonesia dapat dikategorikan memiliki keunggulan komparatif. Dari tahun 1997-2014, perkembangan nilai RCA kopi Indonesia memiliki tren positif di negara ini, sehingga negara Malaysia dapat dikatakan tergolong negara peminat kopi dari Indonesia. Nilai indeks RCA tertinggi di Malaysia mencapai 2,85 tahun 2013 yaitu pada saat nilai ekspor komoditi kopi Indonesia ke Malaysia mencapai nilai 79,71 juta US \$. Namun jika dibandingkan dengan indeks RCA Vietnam di negara Malaysia, terlihat bahwa ekspor kopi Vietnam memiliki daya saing yang lebih tinggi dibandingkan ekspor kopi Indonesia. 


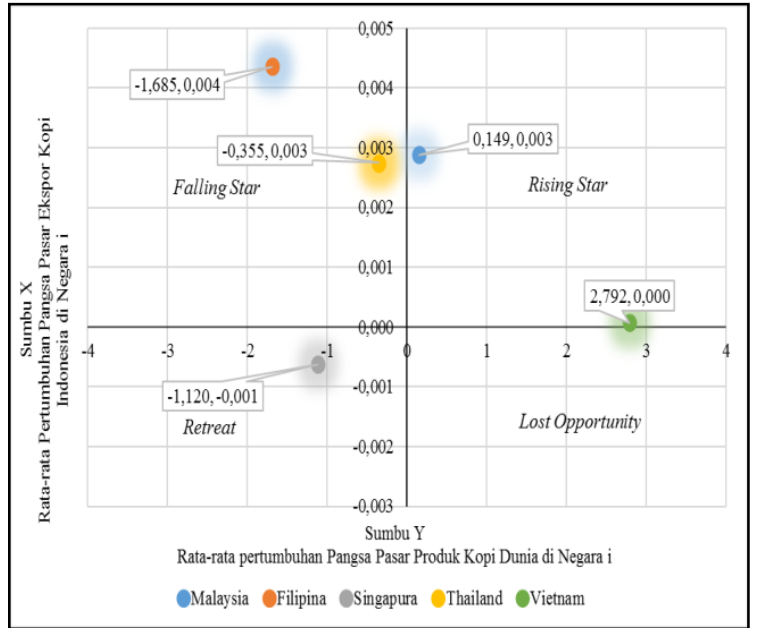

Sumber : UN Comtrade (diolah)

Gambar 5.

Export Product Dynamic (EPD)

komoditi kopi Indonesia ke negaranegara ASEAN tahun 1997-2014

Berdasarkan hasil EPD pada Gambar 5, ekspor komoditi kopi Indonesia di negara Malaysia dan Vietnam termasuk dinamis selama periode penelitian (1997-2014) dengan rata-rata pertumbuhan pangsa pasar kopi Indonesia di Malaysia sebesar 0,0029 dan 0,0001 di Vietnam serta rata-rata pertumbuhan pangsa produk kopi dunia di negara tersebut masing-masing 0,1439 dan 2,7925.

Negara Malaysia dan Vietnam sebagai tujuan ekspor kopi Indonesia berada pada kuadran rising star. Hal ini berarti bahwa ekspor komoditi kopi Indonesia di negara tersebut merupakan produk yang dinamis (pertumbuhannya cepat) selama periode penelitian. Pertumbuhan ekspor kopi Indonesia di dua negara tersebut tergolong kontinu dalam jangka waktu yang panjang. Dengan kata lain, peningkatan pangsa pasar kopi Indonesia di pasar kedua negara tersebut ditengah terjadinya peningkatan pangsa kopi perdagangan dunia di negara tersebut. Pasar komoditi kopi di kedua negara tersebut dapat dikatakan memiliki posisi pasar yang ideal.
Filipina dan Thailand sebagai negara tujuan ekspor kopi Indonesia berada pada kuadran lost opportunity. Hal ini berarti bahwa terjadi penurunan pangsa pasar kopi Indonesia di pasar negara tersebut ditengah peningkatan pangsa pasar produk kopi di perdagangan dunia. Komoditi kopi di negara tersebut masih didominasi oleh komoditi kopi dari negara lain di dunia selain Indonesia. Ekspor komoditi kopi Indoensia tidak mengalami pertumbuhan di pangsa pasar Filipina dan Thailand selama periode penelitian ini. Sementara itu, negara Singapura berada pada kuadran retreat, yang berarti bahwa terjadi penurunan pangsa pasar kopi Indonesia di negara tersebut di tengah penurunan pangsa pasar produk kopi perdagangan dunia di negara tersebut.

Model regresi panel digunakan untuk mengetahui faktor-faktor yang memengaruhi ekspor kopi Indonesia ke negara tujuan ekspor yakni negara Malaysia, Filipina, Singapura, Thailand, dan Vietnam dengan variabel bebas yang digunakan adalah harga riil ekspor kopi ke negara tujuan, harga impor teh di negara tujuan, Produk Domestik Bruto (PDB) negara tujuan, total produksi kopi Indonesia, kurs riil negara tujuan, dan daya saing kopi Indonesia pada periode penelitian tahun 1997-2014.

Terdapat tiga kemungkinan model estimasi regresi data panel yang dapat digunakan yaitu Common Effect Model (CEM), Fixed Effect Model (FEM), dan Random Effect Model (REM). Untuk memilih model estimasi, dapat dilakukan uji formal sebagai berikut.

1. Uji Chow, digunakan untuk memilih model terbaik antara model fixed effect dan common effect.

2. Uji Lagrange Multiplier, digunakan untuk memilih model terbaik antara model random effect dan common effect. 
Jurnal Ilmiah Ekonomi dan Bísnis

Vol. 16. No.2, September 2019: 143-157

EISSN : $2442-9813$

ISSN : $1829-9822$

3. Uji Hausman, digunakan untuk memilih model terbaik antara model fixed effect dan random effect.

Selain itu, pemilihan model estimasi dapat dilakukan dengan melakukan uji secara informal dengan melihat jumlah individu dan series waktunya. Beberapa ahli ekonometri yang tentunya telah membuktikan secara matematis, di mana dikatakan bahwa jika data panel yang dimiliki mempunyai jumlah waktu (T) lebih besar dibandingan jumlah individu (N) maka disarankan untuk menggunakan model fixed effect. Sebaliknya jika data panel yang dimiliki mempunyai jumlah waktu (T) lebih kecil dibandingkan jumlah individu (N) maka disarankan untuk menggunakan model random effect (Nachrowi dan Usman, 2006).

Dalam penelitian ini, model random effect tidak dapat dilakukan karena jumlah individu kurang dari jumlah (series) waktu sehingga hanya akan menggunakan uji statistik Chow dan Lagrange Multiplier. Berikut penghitungan model estimasi yang dihasilkan.

Tabel 4. Hasil estimasi regresi data panel model common effect dan fixed effect

\begin{tabular}{|c|c|c|c|c|}
\hline $\begin{array}{l}\text { Jenis } \\
\text { Estimasi }\end{array}$ & $\begin{array}{l}\text { Variabel } \\
\text { Independen }\end{array}$ & Koefisien & $\begin{array}{l}\mathrm{t} \\
\text { statistik }\end{array}$ & Prob \\
\hline \multirow{7}{*}{$\begin{array}{l}\text { Common } \\
\text { Effect }\end{array}$} & $\mathrm{C}$ & 20,73216 & 2,210 & 0,030 \\
\hline & HXKOPI & $-0,15761$ & $-4,863$ & 0,000 \\
\hline & НМТЕН & 0,30366 & 4,518 & 0,000 \\
\hline & LNPDBHK & $-0,15652$ & $-0,446$ & 0,656 \\
\hline & PRODKOPI & 0,00000 & $-2,298$ & 0,024 \\
\hline & KURSR & $-0,00008$ & $-3,171$ & 0,002 \\
\hline & LNRCA & 1,09023 & 17,176 & 0,000 \\
\hline \multirow{7}{*}{$\begin{array}{l}\text { Fixed } \\
\text { Effect }\end{array}$} & $\mathrm{C}$ & $-3,14517$ & $-0,378$ & 0,707 \\
\hline & HXKOPI & $-0,10095$ & $-4,548$ & 0,000 \\
\hline & НMTEH & 0,18185 & 3,520 & 0,001 \\
\hline & LNPDBHK & 0,75834 & 2,450 & 0,017 \\
\hline & PRODKOPI & 0,00000 & $-1,270$ & 0,208 \\
\hline & KURSR & $-0,00018$ & $-5,111$ & 0,000 \\
\hline & LNRCA & 0,97507 & 20,455 & 0,000 \\
\hline
\end{tabular}

Sumber : hasil olahan

Berdasarkan hasil uji Chow diperoleh bahwa model fixed effect lebih baik daripada model common effect (tolak $H_{0}$ ). Selain itu hasil uji Lagrange Multiplier menunjukkan bahwa model fixed effect lebih baik daripada model random effect. Berikutnya dilakukan pengujian pada struktur varian covariance residual menggunakan uji Lagrange Multiplier (LM). Dari hasil uji LM diperoleh bahwa residual struktur varians - covariance bersifat heteroskedastis dan terdapat cross sectional correlation. Setelah melakukan pemilihan model terbaik, pengujian struktur variancovariance, dan pengujian asumsi klasik, maka diperoleh model yang akan digunakan untuk mengidentifikasi pengaruh variabel-variabel bebas terhadap ekspor komoditi kopi Indonesia. Model yang terpilih adalah model (fixed effect) GLS cross section Seemingly Unrelated Regression (SUR). Selanjutnya berdasarkan uji asumsi klasik diperoleh bahwa model tersebut memenuhi asumsi nonmultikoliniearitas dan normalitas sehingga model estimasi data panel untuk ekspor komoditi kopi Indonesia yang diperoleh :

$$
\begin{gathered}
\text { LNV } \widehat{\text { OLXKOPI }}_{\text {it }}=\left(-0,7965+\mu_{\mathrm{i}}\right) \\
-0,1133 \text { HXKOPI }^{*}{ }_{\text {it }}+0,1289 \text { HMTEH }^{*} \\
\text { it }
\end{gathered}
$$

$+0,6685$ LNPDBHK $^{*}$ it $-0,000001$ PRODKOPI $_{\text {it }}$ $-0,00018$ KURSR $^{*}{ }_{\text {it }}+0,9427$ LNRCA $^{*}{ }_{\text {it }}$

*Signifikan pada alpha $5 \%$,

$$
R_{\text {adj }}^{2}=0,983 ; F_{\text {hitung }}{ }^{*}=521,876
$$

Dari persamaan di atas dapat diketahui bahwa model tersebut memiliki nilai prob (F-statistic) bernilai 0,0000 yang berarti seluruh variabel bebas secara simultan signifikan memengaruhi variabel tak bebas dengan tingkat keyakinan 95 persen. Nilai adjusted $R$-squared sebesar 0,983 menunjukkan bahwa variabel harga riil ekspor kopi, harga impor teh di negara mitra dagang, PDB riil, produksi kopi Indonesia, nilai tukar riil dan RCA mampu menjelaskan variasi volume 
ekspor komoditi kopi Indonesia ke negara-negara ASEAN tujuan ekspor tahun 1997-2014 sebesar 98,3 persen dimana 1,7 persen sisanya dijelaskan variabel lain yang tidak tercakup dalam model.

Tabel 5. Hasil estimasi regresi data panel model fixed effect cross section SUR

\begin{tabular}{|l|l|l|l|}
\hline $\begin{array}{l}\text { Variabel } \\
\text { Independen }\end{array}$ & Koefisien & t statistik & Prob \\
\hline C & $-0,796567$ & $-0,1300$ & 0,8965 \\
\hline HXKOPI & $-0,113322$ & $-4,5670$ & 0,0000 \\
\hline HMTEH & 0,128956 & 5,3480 & 0,0000 \\
\hline LNPDBHK & 0,668522 & 2,9740 & 0,0039 \\
\hline PRODKOPI & $-0,000001$ & $-1,5350$ & 0,1288 \\
\hline KURSR & $-0,000181$ & $-7,9600$ & 0,0000 \\
\hline LNRCA & 0,942759 & 39,8670 & 0,0000 \\
\hline
\end{tabular}

Sumber : hasil olahan

Pengujian secara parsial dapat dilihat dari nilai t-statistic dari tiap variabel bebas. Hasil pengujian yang terdapat pada Tabel 8 menunjukkan bahwa variabel harga riil ekspor kopi Indonesia, harga teh, pertumbuhan PDB, nilai tukar riil, dan RCA signifikan secara parsial berpengaruh terhadap variabel volume ekspor pada tingkat alpha 5 persen. Variabel jumlah produksi kopi Indonesia tidak signifikan berpengaruh secara parsial terhadap volume ekspor kopi Indonesia.

Variabel harga riil ekspor kopi ke negara tujuan ekspor berpengaruh negatif terhadap pertumbuhan volume ekspor kopi ke lima negara tujuan ekspor di kawasan ASEAN tersebut. Nilai koefisien harga riil kopi sebesar 0,113 menunjukkan bahwa setiap kenaikan harga riil ekspor 1 US \$ akan mengurangi permintaan ekspor kopi Indonesia di negara tujuan ekspor sebesar 11,3 persen, dengan asumsi variabel lain konstan (ceteris paribus). Hasil ini sesuai dengan hipotesis penelitian bahwa harga riil ekspor berpengaruh secara negatif terhadap permintaan ekspor kopi Indonesia dan sesuai dengan hasil penelitian Widayanti et al (2009). Namun, pada penelitian Izzany (2015), harga riil ekspor kopi Indonesia signifikan berpengaruh secara positif terhadap volume ekspor kopi Indonesia ke negara Singapura. Izzany (2015) meneliti dari sisi penawaran yaitu adanya peningkatan harga ekspor kopi akan mendorong peningkatan penawaran ekspor kopi Indonesia ke negara tersebut.

Variabel harga teh di negara tujuan ekspor berpengaruh positif terhadap pertumbuhan volume ekspor kopi ke lima negera tujuan. Nilai koefisien harga teh sebesar 0,128 menunjukkan bahwa setiap terjadi kenaikan harga teh sebesar 1 US \$ akan berpengaruh pada peningkatan permintaan volume ekspor kopi Indonesia sebesar 12,8 persen, dengan asumsi variabel lain konstan (ceteris paribus). Hasil ini sesuai dengan hipotesis penelitian yang diajukan bahwa harga teh berpengaruh positif terhadap permintaan ekspor kopi. Kenaikan harga teh akan mendorong pembeli untuk lebih memilih kopi karena sifat dari kopi dan teh adalah memiliki fungsi yang sama.

Variabel PDB riil negara-negara ASEAN pada tingkat signifikansi 5 persen berpengaruh positif terhadap permintaan ekspor kopi Indonesia. Setiap peningkatan PDB sebesar 1 persen akan meningkatkan permintaan ekspor kopi Indonesia sebesar 0,668 persen dengan asumsi variabel lainnya konstan atau dalam kondisi ceteris paribus. Pengaruh PDB terhadap permintaan ekspor kopi sesuai dengan hipotesis yang diharapkan. Hasil ini juga sesuai dengan penelitian Ademe dan Yismaw (2013) dan Waheed dan Abbas (2015) bahwa pendapatan domestik di negara tujuan ekspor berpengaruh positif terhadap ekspor.

Pertumbuhan PDB negara-negara tujuan ekspor yang positif tahun 19972014 menunjukkan kondisi perekonomian yang terus membaik dan merupakan pasar yang potensial selama 18 tahun terakhir. Tingkat perekonomian yang digambarkan 


\section{Jurnal Ilmiah Ekonomi dan Bisnis}

Vol. 16. No.2, September 2019: 143-157

EISSN : $2442-9813$

ISSN : $1829-9822$

di dalam PDB menunjukkan negaranegara ASEAN tersebut memiliki pasar domestik yang mampu menyerap barang impor dalam jumlah yang semakin besar. Dengan demikian, negara-negara ASEAN merupakan negara yang cocok menjadi tujuan ekspor komoditi kopi Indonesia karena memiliki respon positif terhadap barang-barang impor dari negara lain.

Selanjutnya, variabel nilai tukar riil negara tujuan ekspor kopi berpengaruh negatif dan signifikan terhadap volume ekspor komoditi kopi Indonesia ke negara tersebut. Pengaruh variabel nilai tukar riil dapat dilihat melalui nilai koefisien regresi variabel tersebut sebesar 0,000181. Angka itu memiliki arti bahwa setiap terjadi peningkatan (depresiasi) nilai tukar riil ke lima negara tujuan ekspor tersebut akan menurunkan permintaan ekspor kopi 0,0181 persen di negara tersebut, dengan asumsi variabel lain konstan (ceteris paribus). Hasil tersebut sesuai dengan hipotesis yang diduga sebelumnya dan sesuai dengan penelitian Hussien (2015) yang juga menunjukkan pengaruh yang negatif dari nilai tukar riil terhadap ekspor kopi. Peningkatan (depresiasi) nilai tukar riil mata uang negara-negara tujuan ekspor terhadap USD menyebabkan semakin mahalnya barang-barang impor yang masuk ke negara tersebut sehingga berdampak pada penurunan jumlah barang-barang yang dapat dibeli. Di lima negara tujuan ekspor kopi Indonesia menunjukkan kecenderungan mata uang riil yang mengalami apresiasi sehingga berdampak pada peningkatan permintaan barang impor termasuk komoditi kopi dari Indonesia.

Variabel daya saing dengan pendekatan revealed comparative advantage (RCA) memiliki pengaruh yang positif dan signifikan terhadap pertumbuhan volume ekspor kopi Indonesia. Nilai koefisien pada variabel
RCA sebesar 0,9427 menunjukkan bahwa apabila RCA (daya saing) ekspor kopi Indonesia meningkat 1 persen maka akan meningkatkan permintaan ekspor komoditi kopi sebesar 0,9427 persen, dengan asumsi variabel lainnya konstan (ceteris paribus). Daya saing (RCA) ekspor kopi Indonesia ini mengindikasikan seberapa besar kemampuan komoditi kopi mempertahankan pangsa pasar di negaranegara ASEAN tujuan ekspor. Semakin besar nilai RCA kopi Indonesia di pasar negara tujuan ekspor menunjukkan sejauh mana ekspor kopi Indonesia mendominasi pangsa pasar kopi di ASEAN.

\section{KESIMPULAN DAN SARAN}

Beberapa kesimpulan yang dapat disampaikan berdasarkan hasil dan pembahasan yaitu sebagai berikut.

1. Perkembangan ekspor komoditi kopi Indonesia di negara Malaysia, Thailand, dan Vietnam cenderung meningkat sedangkan ekspor komoditi kopi Indonesia di negara Filipina dan Singapura cenderung fluktuatif dan menurun. Ekspor komoditi kopi Indonesia terbesar dicapai di negara Malaysia dengan rata-rata 16.045 ton dan terkecil di negara Vietnam dengan rata-rata 1.259 ton.

2. Berdasarkan indeks RCA, ekspor kopi Indonesia hanya memiliki keunggulan komparatif di atas rata-rata dunia di negara tujuan Malaysia. Berdasarkan hasil EPD, kinerja ekespor komoditi kopi Indonesia di negara Malaysia dan Vietnam termasuk dinamis selama periode penelitian (1997-2014) karena berada pada kuadran rising star.

3. Berdasarkan hasil pemilihan model yang terbaik, variabel harga teh, PDB riil dan indeks daya saing (RCA) signifikan berpengaruh positif terhadap ekspor kopi Indonesia. Variabel harga riil ekspor kopi Indonesia dan nilai tukar riil signifikan berpengaruh negatif terhadap ekspor komoditi kopi 
Indonesia. Sementara variabel produksi kopi domestik Indonesia tidak signifikan berpengaruh terhadap ekspor komoditi kopi Indonesia.

Berikut beberapa saran berdasarkan kesimpulan penelitian. maka berikut beberapa saran yang disampaikan oleh penulis :

1. Dalam rangka meningkatkan permintaan ekspor kopi Indonesia, pemerintah perlu memperluas pangsa pasar ekspor dengan melakukan diversifikasi negara tujuan ekspor ke negara ASEAN lain seperti Myanmar, Laos, dan Kamboja. Selain itu pemerintah dapat menambahkan pengiriman ekspor kopi ke negara tujuan ekspor yang memiliki PDB dan daya saing ekspor kopi Indonesia yang tinggi di ASEAN seperti Malaysia dan Vietnam melalui kebijakan kuota ekspor negara tujuan lainnya.

2. Untuk mendorong daya saing komoditi kopi Indonesia, pemerintah dan petani kopi perlu meningkatkan kualitas hasil kopi dengan melakukan intensifikasi kopi melalui bibit arabika, irigasi kopi pada masa kemarau dan penggunaan pupuk, serta melakukan pengolahan lebih lanjut terhadap biji kopi seperti dekafeinasi (proses penghilangan kafein, fermentasi dan penyangraian untuk menambah pilihan cita rasa kopi ekspor.

3. Pemerintah perlu menjaga kestabilan nilai tukar negara dan sigap terhadap gejolak nilai tukar negara tujuan ekspor agar tidak berimbas pada peningkatan harga ekspor kopi dan penurunan daya beli masyarakat melalui kebijakan moneter. Selain itu, harga komoditi teh di negara tujuan dapat dijadikan pertimbangan untuk memetakan permintaan ekspor kopi Indonesia di ASEAN.

4. Bagi penelitian selanjutnya, cakupan kopi dapat diperluas dengan kopi olahan dengan kode HS 2101. Selain itu, dapat juga menambahkan variabel lain seperti konsumsi kopi domestik dan negara tujuan ekspor, harga ekspor kopi pesaing di pasar ASEAN, volume ekspor negara eksportir lainnya, dan jumlah penduduk negara tujuan ekspor.

\section{DAFTAR PUSTAKA}

Ademe, A.S and Yismaw, M. A. 2013. Ethiopian Coffee Trade Pattern: An Augmented Gravity Modeling Approach. Journal of Economic and Sustainable Development, 4 (17), 110-120.

Asosiasi Eksportir Kopi Indonesia. 2016. Sejarah Kopi di Indonesia. 11 maret 2016. http://www.aekiaice.org/page/sejarah/id

Badan Pusat Statistik. 2013. Buletin Perdagangan Luar Negeri Ekspor Menurut Kelompok Komoditi dan Negara Desember 2013. Jakarta : BPS.

Badan Pusat Statistik. 2014. Buletin Statistik Perdagangan Luar Negeri Ekspor Menurut Kelompok Komoditi dan Negara Desember 2014. Jakarta : BPS.

Badan Pusat Statistik. 2015a. Produk Domestisk Bruto Indonesia Triwulanan 2011-2015. Jakarta : BPS.

Badan Pusat Statistik. 2015b. Pendapatan Nasional Indonesia 2010-2014. Jakarta : BPS.

Baga, Lukman M., Anna Fariyanti, dan Siti Jahroh. 2011. Kewirausahaan dan Daya Saing Agribisnis.Bogor : IPB Press. 
Jurnal Ilmiah Ekonomí dan Bísnís

Vol. 16. No.2, September 2019: 143-157

EISSN : $2442-9813$

ISSN : $1829-9822$

Baltagi, Badi H. 2011. Econometric Fifth Edition. New York : Springer.

Blanchard, Olivier and Johnson, David R. 2012. Macroeconomics Sixth Edition. New Jersey: Prentice Hall.

Ekananda, Mahyus. 2014. Analisis Ekonometrika Data Panel. Jakarta : Mitra Wacana Media.

Ekananda, Mahyus. 2015. Perdagangan Internasional. Jakarta : Erlangga.

Greene, William H. 2012. Econometric Analysis Seventh Edition. New York : Pearson.

Halwani, Hendra. 2005. Ekonomi Internasional dan Globalisasi Ekonomi (2nd ed). Jakarta : Ghalia Indonesia.

Hussien, Hassen Beshir. (2015). Determinants of Coffee Export Supply in Ethiopia: Error Correction Modeling Approach. Journal of Economics and Sustainable Development, 6 (5), 31-37.

Hill, R. Carter, William E. Griffiths, dan Guay C. Lim. 2011. Principles of Econometrics Fourth Edition. USA : John Wiley \& Sons.

International Coffee Organization. 2015. Historical Data on the Global Coffee Trade. 17 desember 2015. http://www.ico.org/new historica l.asp

International Coffee Organization. (27 Februari 2014). Coffee Consumption in East and Southeast Asia : 1990 - 2012. International Coffee Council $112^{\text {th }}$ Session.
Izzany, Shiraz Fayeza. 2015. Analisis Kinerja Ekspor Kopi Indonesia ke Pasar ASEAN dan Faktor-faktor yang mempengaruhi dalam skema CEPT-AFTA [skripsi]. Bogor : Institut Pertanian Bogor.

Kementerian Perdagangan Republik Indonesia. 2011. Kajian Kebijakan Pengembangan Diversifikasi Pasar dan Produk Ekspor. Jakarta : Kemendagri.

Krugman, Paul R. dan Obstfeld, Maurice. 1991. Ekonomi Internasional Teori dan Kebijakan. $2^{\text {nd }}$ edition. (Faisal H. Basri, trans). Jakarta : Raja Grafindo Persada.

Muzendi, Agustina S. Mori. 2014. Integrasi Pasar dan Dampak Kebijakan Non Tarif terhadap Permintaan Ekspor dan Daya Saing Kopi Indonesia di Pasar Internasional [Tesis]. Bogor : Instititut Pertanian Bogor.

Peraturan Menteri Perdagangan Republik Indonesia Nomor : 10/MDAG/PER/5/2011 tentang Perubahan atas Peraturan Menteri Perdagangan Nomor : 41/MDAG/PER/9/2009 tentang Ketentuan Ekspor Kopi.

Pindyck, Robert S. dan Rubinfeld, Daniel L. 1998. Microeconomics Eight Edition. New Jersey : Prentice Hall.

Rahardjo, Pudji. 2012. Kopi : Panduan Budi Daya dan Pengolahan Kopi Arabika dan Robusta. Jember : Penebar Swadaya

Salvatore, Dominick. 1995. International Economic Fifth Edition. New Jersey : Prentice Hall 
Sihono, Teguh. 2009. Dampak Krisis

Finansial Amerika Serikat

Terhadap Perekonomian Asia.

Krisis Finansial Amerika Serikat dan Perekonomian Asia, 6(1), 120.

Tambunan, Tulus. 2011. Perekonomian Indonesia : Kajian Teoretis dan Analisis Empiris. Bogor : Ghalia Indonesia.

United Nation Commodity Trade. 2016. International Trade Statistics Database. 10 maret 2016. http://www.comtrade.un.org/data/

Waheed, Abdul and Abbas, Shujaat. (2015). Potential Export Markets for Bahrain: A Panel Data Analysis. International Journal of Trade, Economics and Finance, 6 (3), 165-169.

Widayanti, Sri, S. M. Kiptiyah, dan M. Iksan Semaoen. (2009). Analisis Ekspor Kopi Indonesia. Wacana, 12 (1), 192-203.

Winantyo, R., R.D. Saputra, S.Fitriani, R. Morena, A. Kosotali, G. Saichu, U.R. Sholihah, A.Rachmanto, D. Gandara. 2008. Masyarakat Ekonomi ASEAN (MEA) 2015 Memperkuat Sinergi ASEAN Di Tengah Kompetisi Global. Jakarta : Bank Indonesia. 